Luma Sh. Al-Saadi*, Valentine C. Eze and Adam P. Harvey

\title{
A reactive coupling process for co-production of solketal and biodiesel
}

https://doi.org/10.1515/gps-2019-0020

Received September 12, 2018; accepted March 11, 2019.

\begin{abstract}
A "reactive coupling" process for one-pot transesterification of rapeseed oil into fatty acid methyl esters (FAME) for biodiesel, and in situ acetalisation of the glycerol by-product to solketal was investigated by both an experimental and a kinetic modelling approach. The aim was to develop a process with a more valuable co-products than glycerol, and to minimise glycerol production. The results showed that a one-stage reactive coupling achieved a solketal yield of $39.5 \pm 5.1 \%$ and FAME yield of $99 \%$ after $8 \mathrm{~h}$ at 10:7:1 of methanol: acetone: oil molar ratio. However, based on these results and the predictions of the kinetic model developed, a "two-stage" reactive coupling process was investigated, in which some of the acetone was added later in the process. The two-stage process was demonstrated to achieve up to $98 \pm 0.5 \%$ FAME and $82 \pm 4 \%$ solketal yields under the same operating conditions.
\end{abstract}

Keywords: reactive coupling; biodiesel; solketal; kinetic modelling; design of experiment statistics

\section{Introduction}

Due to fossil fuel depletion and global warming, biofuel production has become significant over the last 25 years, in 2016 accounting for 351 kte in the UK [1]. Biodiesel is synthesised via the reaction of triglycerides, usually vegetable oils, with alkyl alcohols, usually methanol. The biodiesel (the fatty acid methyl ester (FAME) of the triglyceride) is the main product, but glycerol is a significant by-product (10-20\% of biodiesel, by volume). Co-production of glycerol in the conventional biodiesel processes has little economic advantage for biodiesel manufacturers, as the huge rise in global glycerol production has caused

\footnotetext{
* Corresponding author: Luma Sh. Al-Saadi, School of Engineering, Newcastle University Newcastle upon Tyne, NE1 7RU, United Kingdom, e-mail: l.al-saadi@newcastle.ac.uk, lumashihab201@gmail.com
}

Valentine C. Eze and Adam P. Harvey, School of Engineering, Newcastle University Newcastle upon Tyne, NE1 7RU, United Kingdom its oversupply, significantly reducing the glycerol price [2]. Glycerol production is reported to have increased from 200,000 te in 2003, to over 2 Mte in 2011, and this is predicted to rise to over 6 Mte by 2025 [3]. One way to improve the economics of biodiesel production is to convert the glycerol into valuable products. Indeed, many alternatives have been suggested to utilize glycerol in many fields such as, animal food, drugs, cosmetics, tobacco, fuel additives, waste treatment and production of different chemicals [4-6]. Previous studies have shown that glycerol can be converted to many valuable chemicals such as 1,3-propanediol [7], citric acid [8], polyhydroxyalkanoates (PHA) [9], glycerol carbonate [10], glycerol ethers [11], fuel extender [12] and solketal [13].

Solketal production is one of the most economical and promising ways of utilising glycerol. The process involves reacting the glycerol with acetone in the presence of an acid catalyst [13]. The reaction of acetone and glycerol to produce solketal is shown in Figure 1. Solketal is a valuable product used in the pharmaceutical industry and as a plasticizer in the polymer industry [14]. Another important future use is as an additive to improve biodiesel's fuel properties by reducing its viscosity and improving fuel stability $[15,16]$.

Although glycerol from the biodiesel process can be converted to valuable chemicals, glycerol recovery and upgrading requires various separation and purification steps. A previous study has shown that acetone can be used as a co-solvent in biodiesel production, to increase alcohol and oil miscibility [17]. However, the acetone must be separated from the final product [18], which increases costs. Applications of integrated process, such as reactive distillation [19] and reactive coupling [20], could be less expensive than conventional reaction for biodiesel production, and this technique could lead to reduction in the required equipment and energy. Solketal co-production through reactive coupling of triacetin transesterification with condensation of the glycerol by-product with acetone has been demonstrated in a recent study [20]. Although triacetin, a short chain triglyceride, was used, the study suggests that this could be of potential application to the long-chain (typically C14-C20) fatty acids found in naturally occurring vegetable oils. It is envisaged that a 
<smiles>OCC(O)CO</smiles>

Glycerol
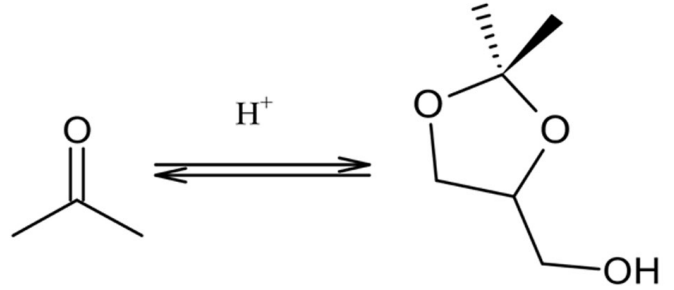

Acetone 2,2-dimethyl-[1,3]

dioxane-4-yl)-methanol

(five-membered solketal,5)

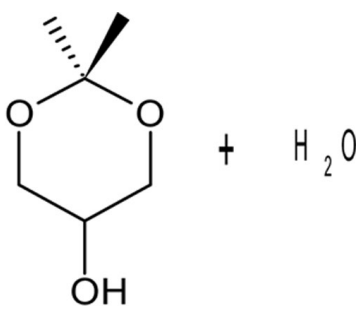

2,2-dimethyldioxane-5-ol(sixmembered acetal,6)

Figure 1: Acid-catalysed reactions of glycerol and acetone to produce solketal.

modification of the biodiesel processing method, via in situ reactive coupling of glycerol condensation with acetone during triglyceride transesterification, could be applied to produce biodiesel and solketal, greatly reducing the glycerol production in biodiesel plants. In situ reactive coupling of glycerol by-product and acetone will changes the reaction rates and reaction equilibrium, and might be hoped to reduce the methanol recycling requirement.

\section{Materials and methods}

\subsection{Materials}

Anhydrous methanol (99.8\% purity), 2,2-dimethyl 1,3-dioxalane-4-methanol (solketal) (99\% purity), acetone (98\% purity), 4- Dodecylbenzenesulfonic acid (DBSA) (98\% purity), 2-propanol (99\% purity), methyl heptadecanaote (99\% purity), glycerol (99\% purity), triethylamine (99\% purity) and high-purity grade silica gel (Davisil Grade 635, pore size $60 \AA$ A, 60-100 mesh) were purchased from Sigma-Aldrich. The rapeseed oil (RSO) used was supplied from Henry Colbeck Ltd, UK.

\subsection{Experimental methods}

The process parameters for the coupling of glycerol transformation to solketal into biodiesel production reactions were investigated using a Design of Experiment statistics (DoE) at methanol to oil molar ratio of 10:1, 0.5 mole of DBSA catalyst per mole of the oil, acetone to oil molar ratio between 2:1-10:1, reaction times of 1-4 $\mathrm{h}$ and $0-100 \mathrm{wt} \%$ of silica gel as a dehydrating agent. Silica gel was added into the reaction mixture to remove reactively-formed water from the system, because of the thermodynamic equilibrium limitations in conversions of glycerol to solketal, due to the productions of water as a by-product [21]. The silica gel was activated by drying in a vacuum oven (OV-11/12) at $120^{\circ} \mathrm{C}$ for $24 \mathrm{~h}$ before use. The reactions were performed at a constant reaction temperature of $50^{\circ} \mathrm{C}$, in a three-necked $250 \mathrm{~mL}$ batch reactor equipped with a heater-stirrer and ports for connections to a condenser, sampling port, and feed input/temperature probe.

A condenser was used to prevent acetone evaporation, and the entire system was sealed before starting the experiment. The acetone, methanol, RSO and catalyst were preheated in reservoirs inside hot water bath before they were transferred into the reaction vessel. The required amounts of acetone, methanol, RSO and silica gel were transferred into the batch reactor, and heated to the reaction temperature. This was followed by additions of the required amount of an acid catalyst. An organosulphonic acid (DBSA) was selected as the catalyst for this process because of its surfactant-like nature, high rate of reaction, and low corrosivity compared to mineral acid catalysts [22]. A preliminary investigation of the reaction showed that mixing speeds of $800 \mathrm{rpm}$ or more were necessary to ensure that the reaction is masstransfer independent. The reactants were mixed vigorously at $800 \mathrm{rpm}$ and the reaction temperature of $50^{\circ} \mathrm{C}$. Samples were collected for analysis at various time intervals, from 1-240 min. Minitab 17 statistical software (box Behnken design), with stepwise methodology, was applied to analyse the experimental results. Statistical models that describe the FAME and solketal yields (responses) were obtained from the experimental data analysis, as a function of the process variables.

A two-stage process for conversions of the RSO to FAME and solketal was also performed, by addition of acetone after the reaction has attained high RSO to FAME and glycerol conversions, in an attempt to compare with the one-stage process, and to maximise the glycerol to solketal conversions. The two-stage experiments consisted of an initial RSO transesterification at 10:1 methanol to 
oil molar ratio, $50^{\circ} \mathrm{C}$ temperature, $0.5: 1$ of catalyst to oil molar ratio, and reaction time of $4 \mathrm{~h}$, followed by in situ acetalisation of the produced glycerol by addition of acetone at 4:1 acetone to RSO molar ratio and reacting for $4 \mathrm{~h}$ in the second step. The RSO transesterification in the first step was left to reach high FAME yields (near complete conversion), so that there could be high glycerol content in the reaction medium to increase the rate of acetalisation in the second step.

\subsection{Sample analysis}

All the samples collected were quenched with triethylamine immediately. Approximately 100-200 mg of each sample was weighed into a $2 \mathrm{~mL}$ of gas chromatography (GC) vials, and $1 \mathrm{~mL}$ of $10 \mathrm{gm} / \mathrm{mL}$ of methyl heptadecanoate $\left(\mathrm{C}_{17}\right)$ prepared in 2-propanol was added to samples and the mixtures homogenised. The $\mathrm{C}_{17}$ was prepared by dissolving of $1000 \mathrm{mg}$ of methyl heptadecanaote in a $100 \mathrm{~mL}$ of 2-propanol. A 5890 series Hewlett Packard gas chromatograph (GC) was used to analyse the prepared samples. The GC was equipped with a capillary column with dimensions of $30 \mathrm{~m}$ length, $0.32 \mathrm{~mm}$ inner diameter and $0.25 \mu \mathrm{m}$ film thickness. The GC oven temperatures were programmed at: initial temperature of $60^{\circ} \mathrm{C}$ held for $4 \mathrm{~min}$, followed by temperature ramp from $60^{\circ} \mathrm{C}$ to $250^{\circ} \mathrm{C}$ at a rate of $15^{\circ} \mathrm{C} / \mathrm{min}$, and held for $7 \mathrm{~min}$. The analytes were calculated from their peak areas referenced against the internal standard. FAME contents in the samples were quantified using the BS EN 14103:2003 [23], whereas the solketal was quantified using calibration data obtained from the response factors of the solutions of solketal and the methyl heptadecanoate standard prepared in a 2-propanol. A solketal response factor against the methyl heptadecanoate standard was determined as 0.43 . The conversions of FAME and solketal were calculated using Eq. 1 and Eq. 2, respectively.

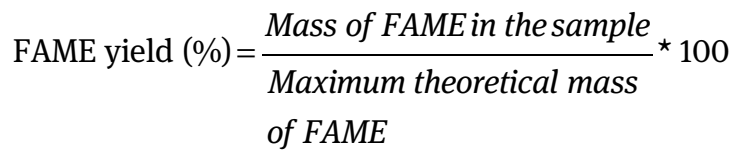

Solketal yield $(\%)=\frac{\text { Mass of solketal in the sample }}{\text { Maximum theoretical mass of }} \star 100$ solketal

Water contents of the samples were determined using a Coulometric Karl Fischer titrator (C30X Coulometer equipped with a generator cell without diaphragm, Mettler Toledo, UK), which measures water contents to $0.1 \mu \mathrm{g}$ resolution. The titrator was calibrated using water standards (Karl Fischer Aqualine ${ }^{\mathrm{TM}}$ water standard, Fischer Scientific, UK) before it was used for the analysis. The measurements of the water contents of the samples were used to determine the effectiveness of the silica in removal of the reactively-formed water.

\subsection{Kinetic model}

Reaction kinetics for homogenous catalysis of triglyceride transesterification have been studied for acid $\left(\mathrm{H}_{2} \mathrm{SO}_{4}\right)$ and base $(\mathrm{NaOBu})$ catalysts, where a pseudo first-order reaction was reported at 30:1 alcohol-to-oil molar ratio, and second-order at 6:1 alcohol to oil molar ratio [24]. Transesterification of soybean oil and methanol at 6:1 of methanol to oil molar ratio using $\mathrm{NaOH}$ catalyst was reported to be initially mass transfer-controlled, followed by a kinetically controlled second-order reaction [25]. Methanolysis of palm oil at 6:1 molar ratio in the presence of $\mathrm{KOH}$ catalyst also has been shown to be secondorder initially, followed by pseudo-first or zero-order kinetics [26]. However, it has been generally accepted that triglyceride transesterification occurs via three consecutive steps [27], as shown in Eq. 3-5, where: MA is methanol, TG is triglyceride, $\mathrm{DG}$ is diglyceride, $\mathrm{MG}$ is monoglyceride, and GL is glycerol. The overall reaction is shown in Eq. 6.

$$
\begin{aligned}
& T G+M A \stackrel{k 1 / k 2}{\longleftrightarrow} F A M E+D G \\
& D G+M A \stackrel{k 3 / k 4}{\longleftrightarrow} F A M E+M G \\
& M G+M A \stackrel{k 5 / k 6}{\longleftrightarrow} F A M E+G L
\end{aligned}
$$

Overall reaction

$$
T G+M A \stackrel{k t / k t-1}{\longrightarrow} 3 F A M E+G L
$$

Kinetic rate expressions for the triglyceride transesterification $[28,29]$ are shown in Eq. 7-12 below, where $r_{A}$ is the rate of formation of species $A\left(\mathrm{~mol} \cdot \mathrm{L}^{-1} \cdot \mathrm{s}^{-1}\right)$, $[\mathrm{A}]$ is the concentration of species $\mathrm{A}\left(\mathrm{mol} \cdot \mathrm{L}^{-1}\right)$, and $\mathrm{k}_{\mathrm{i}}$ is the rate constants of the individual reaction steps $\left(\mathrm{L} \cdot \mathrm{mol}^{-1} \cdot \mathrm{s}^{-1}\right)$.

$$
\mathrm{r}_{\mathrm{TG}}=\frac{\mathrm{d}[\mathrm{TG}]}{\mathrm{dt}}=-\mathrm{k}_{1}[\mathrm{TG}][\mathrm{MA}]+\mathrm{k}_{2}[\mathrm{DG}][\mathrm{FAME}]
$$




$$
\begin{aligned}
\mathrm{r}_{\mathrm{DG}}= & \mathrm{k}_{1}[\mathrm{TG}][\mathrm{MA}]+\mathrm{k}_{4}[\mathrm{MG}][\mathrm{FAME}]-\mathrm{k}_{2}[\mathrm{DG}][\mathrm{FAME}] \\
& -\mathrm{k}_{3}[\mathrm{DG}][\mathrm{MA}] \\
\mathrm{r}_{\mathrm{MG}}= & \mathrm{k}_{3}[\mathrm{DG}][\mathrm{MA}]+\mathrm{k}_{6}[\mathrm{GL}][\mathrm{FAME}]-\mathrm{k}_{4}[\mathrm{MG}][\mathrm{FAME}] \\
& -\mathrm{k}_{5}[\mathrm{MG}][\mathrm{MA}] \\
\mathrm{r}_{\mathrm{FAME}}= & \frac{\mathrm{d}[\mathrm{FAME}]}{\mathrm{dt}}=\mathrm{k}_{1}[\mathrm{TG}][\mathrm{MA}]+\mathrm{k}_{3}[\mathrm{DG}][\mathrm{MA}]+\mathrm{k}_{5}[\mathrm{MG}][\mathrm{MA}] \\
& -\mathrm{k}_{2}[\mathrm{DG}][\mathrm{FAME}]-\mathrm{k}_{4}[\mathrm{MG}][\mathrm{FAME}]-\mathrm{k}_{6}[\mathrm{GL}][\mathrm{FAME}] \\
& \mathrm{r}_{\mathrm{GL}}=\frac{\mathrm{d}[\mathrm{GL}]}{\mathrm{dt}}=\mathrm{k}_{5}[\mathrm{MG}][\mathrm{MA}]-\mathrm{k}_{6}[\mathrm{GL}][\mathrm{FAME}] \\
& \mathrm{r}_{\mathrm{MA}}=\frac{\mathrm{d}[\mathrm{MA}]}{\mathrm{dt}}=-\frac{\mathrm{d}[\mathrm{FAME}]}{\mathrm{dt}}
\end{aligned}
$$

In a reactive coupling process, the kinetic rate expressions must be modified, due to the reaction of MG with acetone in Eq. 13 and reactions of glycerol with acetone shown in Eq. 14, where AC is acetone, and FA-solketal is fatty acid solketal.

$$
\begin{aligned}
& M G+A C \stackrel{k 7 / k 8}{\longleftrightarrow} F A-\text { Solketal }+\mathrm{H}_{2} \mathrm{O}
\end{aligned}
$$

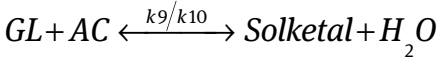

The kinetic rate expressions of solketal, acetone, water, MG and GL can be described as below in Eq. 15-19.

$$
\begin{gathered}
\mathrm{r}_{\text {solketal }}=\mathrm{k}_{9}[\mathrm{GL}][\mathrm{AC}]-\mathrm{k}_{10}[\text { solketal }]\left[\mathrm{H}_{2} \mathrm{O}\right] \\
\mathrm{r}_{\mathrm{AC}}=-\mathrm{k}_{9}[\mathrm{GL}][\mathrm{AC}]+\mathrm{k}_{10}[\text { solketal }]\left[\mathrm{H}_{2} \mathrm{O}\right]-\mathrm{k}_{7}[\mathrm{MG}] \\
+\mathrm{k}_{8}[\mathrm{FA}-\text { solketal }]\left[\mathrm{H}_{2} \mathrm{O}\right] \\
\mathrm{r}_{\mathrm{H}_{2} \mathrm{O}}=\mathrm{k}_{9}[\mathrm{GL}][\mathrm{AC}]-\mathrm{k}_{10}[\text { solketal }]\left[\mathrm{H}_{2} \mathrm{O}\right] \\
+\mathrm{k}_{7}[\mathrm{MG}][\mathrm{AC}]-\mathrm{k}_{10}[\mathrm{FA}-\text { solketal }]\left[\mathrm{H}_{2} \mathrm{O}\right] \\
\mathrm{r}_{\mathrm{MG}}=\mathrm{k}_{3}[\mathrm{DG}][\mathrm{MA}] \\
+\mathrm{k}_{6}[\mathrm{GL}][\mathrm{FAME}]-\mathrm{k}_{4}[\mathrm{MG}][\mathrm{FAME}]-\mathrm{k}_{5}[\mathrm{MG}][\mathrm{MA}] \\
-K_{7}[\mathrm{MG}][\mathrm{AC}]+K_{8}[\mathrm{FA}-\text { Solketal }]\left[\mathrm{H}_{2} \mathrm{O}\right] \\
\mathrm{r}_{\mathrm{GL}}=\frac{\mathrm{d}[\mathrm{GL}]}{\mathrm{dt}}=\mathrm{k}_{5}[\mathrm{MG}][\mathrm{MA}]-\mathrm{k}_{6}[\mathrm{GL}][\mathrm{FAME}]-K_{9}[\mathrm{GL}][\text { AC }] \\
\quad-K_{10}[\text { Solketal }]\left[\mathrm{H}_{2} \mathrm{O}\right]
\end{gathered}
$$

Numerical simulations of the reaction kinetics was done using MATLAB ODE45 solver, based on Eq. 7-12 and
Eq. 15-19, to obtain a model for the in situ reactive coupling of glycerol acetalisation to triglyceride transesterification. The initial rate constants used for the numerical modelling were obtained from an existing study for a vegetable oil transesterification [28], coupled with values determined from preliminary experiments between pure glycerol and solketal in the presence of DBSA catalyst. The model adjusts the initial rate constants to minimise the sum of squared errors (SSE $<0.05$ ) between the experimental and the model

\begin{tabular}{|c|c|c|c|c|}
\hline \multicolumn{3}{|c|}{ Operating parameters } & \multicolumn{2}{|c|}{ Experimental conversion } \\
\hline $\begin{array}{l}\text { Acetone: } \\
\text { oil molar ratio }\end{array}$ & $\begin{array}{r}\text { Residence } \\
\text { time (hr) }\end{array}$ & $\begin{array}{l}\text { Silica loading: } \\
\text { water (wt\%) }\end{array}$ & $\begin{array}{r}\text { Solketal } \\
\text { yield (\%) }\end{array}$ & $\begin{array}{r}\text { FAME yield } \\
(\%)\end{array}$ \\
\hline 2 & 1 & 50 & 24 & 45 \\
\hline 6 & 2.5 & 50 & 34 & 71.3 \\
\hline 6 & 1 & 100 & 11 & 27 \\
\hline 6 & 2.5 & 50 & 34 & 71.3 \\
\hline 2 & 2.5 & 0 & 37 & 89 \\
\hline 6 & 2.5 & 50 & 34 & 71.3 \\
\hline 10 & 1 & 50 & 7.3 & 9 \\
\hline 10 & 2.5 & 0 & 20 & 53 \\
\hline 10 & 2.5 & 100 & 21 & 53 \\
\hline 2 & 4 & 50 & 44 & 99.9 \\
\hline 2 & 2.5 & 100 & 38 & 89 \\
\hline 10 & 4 & 50 & 27.3 & 66 \\
\hline 6 & 4 & 100 & 31.46 & 84 \\
\hline 6 & 4 & 0 & 30.5 & 84 \\
\hline 6 & 1 & 0 & 10 & 27 \\
\hline
\end{tabular}
predictions. The actual rate constants for the reactions were the computed $\mathrm{k}$ values that give best fit to the experimental data at minimised SSE [28]. The model was applied to predict the effects of catalyst concentrations, reaction temperature and residence time, on conversions of RSO to FAME and solketal, and these were validated using experimental data. The experimental and numerical modelling approaches were combined to identify the reaction conditions necessary for high FAME and solketal yields.

\section{Results and discussion}

\subsection{Effects of process parameters on reactive coupling for FAME and solketal co-productions}

Table 1 shows the RSO conversions to solketal and FAME at various acetone molar ratios, residence time, and silica loading, and fixed conditions of 10:1 of methanol to oil molar ratio, 0.5 of catalyst to oil molar

Table 1: DoE model and the conversion of solketal and FAME. 

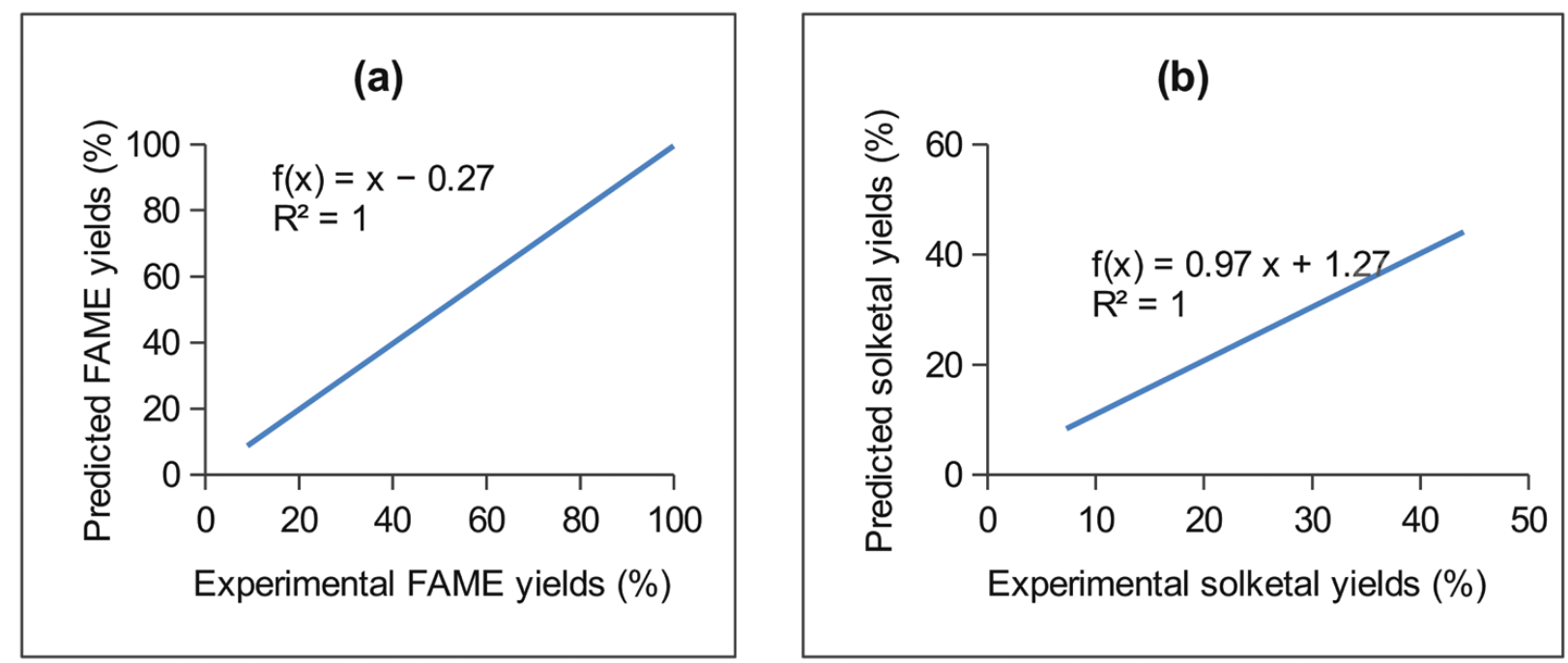

Figure 2: Plots of the experimental versus predicted values for (a) FAME and (b) solketal, for the DoE parametric screening of reaction variables in a single-stage reactive coupling of RSO conversions to FAME and solketal.

ratio and $50^{\circ} \mathrm{C}$. The experimental data were analysed with Minitab 17, using the stepwise response surface method (box Behnken design), to evaluate the effects of the process conditions. The predictive models in Eq. 20 and Eq. 21 were generated from the experimental data for the conversions of the RSO to FAME and solketal respectively, where AMR is the acetone to RSO molar ratio, SL is the silica loading (wt\%) based on the RSO, and $t$ is the reaction time $(\mathrm{h})$. The fit and the experimental data are shown in Figure 2 (R2 $\geq 0.99$ ).

$$
\begin{aligned}
\text { FAME yield }(\%)= & 6.35-4.483^{\star} \mathrm{AMR}+54.34^{\star} \mathrm{t} \\
- & 7.1^{\star} \mathrm{t}^{2} \\
\text { Solketal yield }(\%)= & 2.19-2.017^{\star} \mathrm{AMR}+24.47^{\star} \mathrm{t} \\
& +0.2001^{\star} \mathrm{SL}-3.563^{\star} \mathrm{t}^{2} \\
& -0.001901^{\star} \mathrm{SL}^{2}
\end{aligned}
$$

The effects of acetone to RSO molar ratio, residence time, and silica loading (wt\%) on FAME and solketal productivity are shown in Figure 3. The contour plots in Figures $3 \mathrm{a}$ and $3 \mathrm{~b}$, show that 2:1 acetone to oil molar ratio was optimal value for both the FAME and solketal yields. The decrease in yield above this value was attributed to dilution of the reaction mixture by the excess acetone, which reduces reaction rates. Similar findings have been reported, where it was observed that large excesses of methanol and acetone could reduce the concentrations of glycerol, resulting in reduced reaction rates [20]. Silica gel was added as it can absorb water, so could remove the reactively- formed water, leading to higher solketal yields. As shown in Figures 3c and 3d, increasing the silica gel loading resulted in higher solketal yields, as expected.
However, further addition of silica gel above $50 \mathrm{wt} \%$ did not increase the solketal yields, indicating that $50 \mathrm{wt} \%$ of silica loading could absorb substantial amounts of the reactively-formed water from the reaction system. Table 2 clearly shows the activity of silica in removal of the reactively formed water, indicating that $50 \mathrm{wt} \%$ of silica can remove of up to $83 \%$ of water produced in the system.

The silica gel loading had no effect on the FAME yields, as illustrated by the empirical model in Eq. 20. It was observed that less than $45 \%$ conversion of the reactivelyformed glycerol to solketal could be obtained even after $4 \mathrm{~h}$ reaction time using single-stage process. Complete online conversion of the glycerol produced from the RSO could not be achieved. This observation is consistent with an existing study which reported that even in acetalisation of pure glycerol, the acetalisation reaction is limited to $75-76 \%$ of solketal conversion by equilibrium [21].

The one-stage and two-stage processes were compared at 7:1 of acetone to RSO molar ratio, $50^{\circ} \mathrm{C}, 8 \mathrm{~h}$ and 0.5 of DBSA to oil molar ratio (Figure 4). The results showed that a $39.5 \pm 5.1 \%$ solketal yield was obtained from the one-stage process, as compared to $82 \pm 4 \%$ for the two-stage process where acetone was added after $4 \mathrm{~h}$. The FAME yields were $\geq 98$ for both one-stage and two-stage processes

It was observed that $97 \%$ of the solketal formed was of the cyclic five-membered acetal form, whereas the cyclic six-membered acetal constituted the remaining $3 \%$. The proportions of the five- and six-membered cyclic acetals in this study are consistent with other reports: $98 \%$ selectivity of a five-membered ring (2,2-dimethyl-[1,3] dioxolan-4-yl) and $2 \%$ of six-membered ring (2,2-dimethyl[1,3]dioxolan-4-yl) [15,30]. 

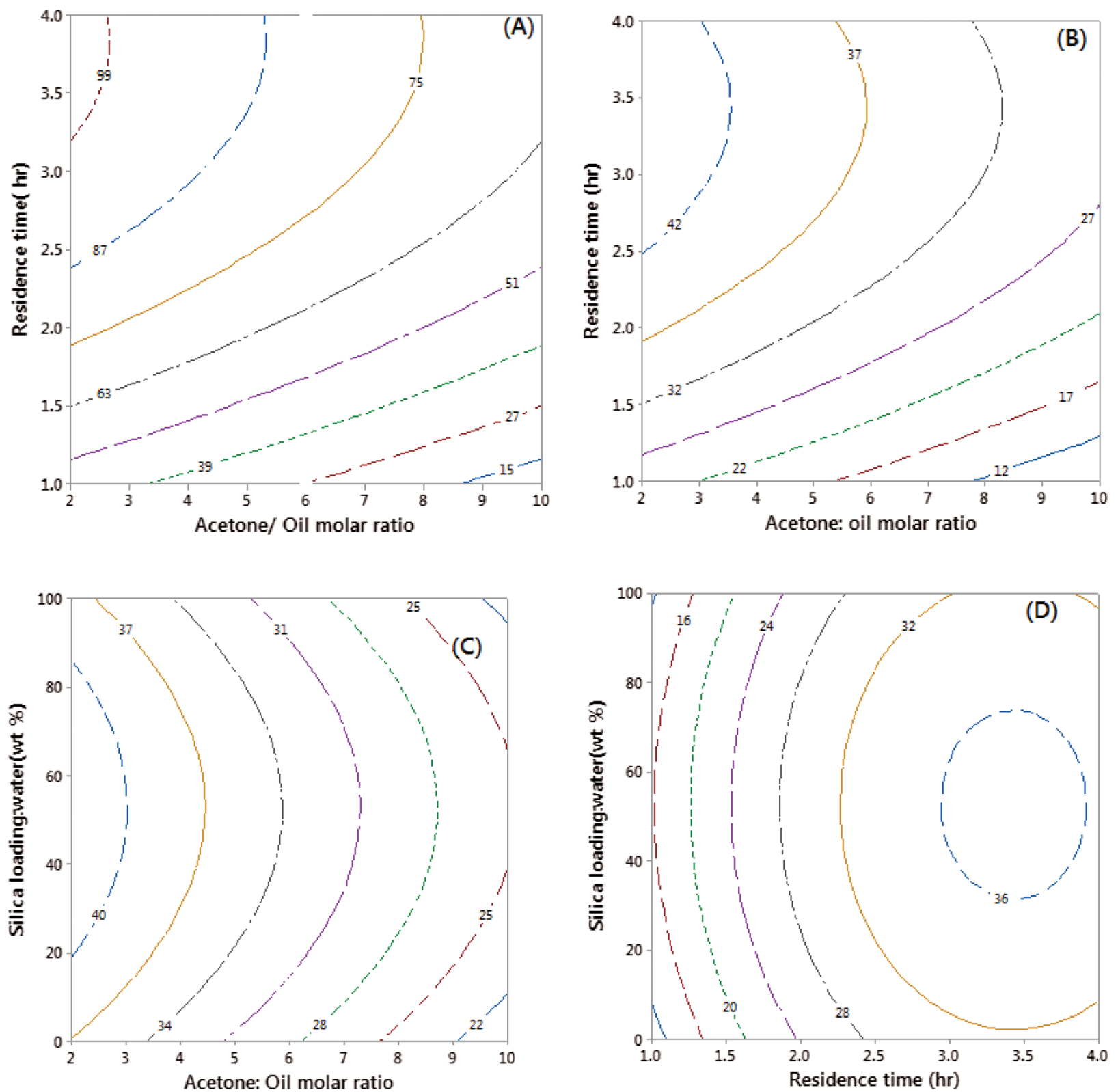

Figure 3: The effects of reaction time and acetone-to-RSO molar ratio on the yields of FAME (a) and solketal (b) for reactions at 50 wt $\%$ of silica gel loading / 1 mol RSO; and the effects of silica loading on the solketal yields, at different acetone molar ratios (c), and reaction times (d).

Table 2: Water removal by silica for reactions at 2:1 of acetone to oil molar ratio, $10: 1$ of methanol to oil molar ratio, 0.5 mole of $\mathrm{DBSA} / 1 \mathrm{~mol} \mathrm{RSO}$ and $50^{\circ} \mathrm{C}$.

Time Solketal Expected $\mathrm{H}_{2} \mathrm{O}$ Measured $\mathrm{H}_{2} \mathrm{O} \quad \mathrm{H}_{2} \mathrm{O}$ removed $(\mathrm{min}) \quad$ yield (\%) content (wt \%) content (wt \%) by Silica (wt\%)

\begin{tabular}{lrrrr}
\hline 0 & 0 & - & 0.71 & 0 \\
30 & 5.88 & 0.80 & 0.77 & 3.87 \\
60 & 15.61 & 2.13 & 0.79 & 63 \\
120 & 32.06 & 4.37 & 0.81 & 81.45 \\
180 & 39.26 & 5.35 & 0.97 & 82 \\
240 & 44.10 & 6.01 & 0.98 & 83.7 \\
\hline
\end{tabular}

\subsection{Kinetic model for reactive coupling of RSO transesterification with glycerol acetalisation}

Based on the MATLAB model, the conditions required to achieve high solketal yields were identified. Figure 5, below, shows the experimental data and the modelpredicted reaction profile, for the reactive coupling of biodiesel and solketal at acetone to rapeseed oil of 4:1 acetone molar ratio, $50^{\circ} \mathrm{C}, 10: 1$ of methanol to rapeseed oil molar ratio and 0.5 of catalyst to oil molar ratio. The model predictions (represented by dotted lines) closely 
match the experimental data (represented by data points).

The rate constants for the reactive coupling reaction of RSO transesterification with in situ by-product glycerol acetalisation using DBSA catalyst at $50^{\circ} \mathrm{C}$ reaction temperature are shown in Table 3 . The rate constant for the DBSA catalyst was 163 times lower than the rate constant for base catalysis [28], but base catalysis is of

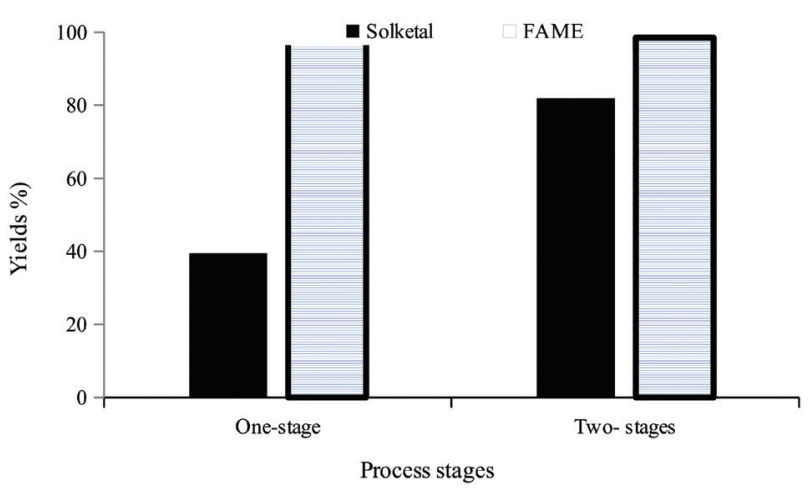

Figure 4: One- and two-stage processes for the reactive coupling of FAME and solketal co-productions at 7:1 of acetone to oil molar ratio, 0.5 of DBSA catalyst concentration, $50^{\circ} \mathrm{C}, 8 \mathrm{~h}$ and $10: 1$ of methanol to oil molar ratio.

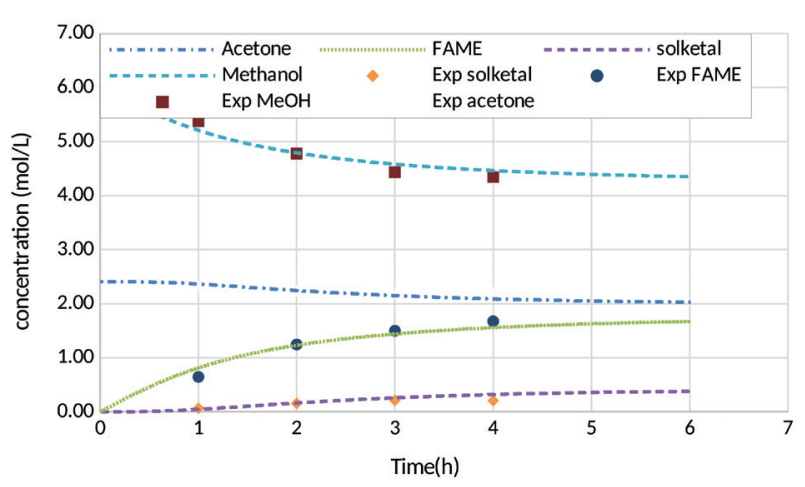

Figure 5: Prediction by kinetic model at $50^{\circ} \mathrm{C}, 0.5$ of catalyst to oil molar ratio, and (1:4) of oil to acetone molar ratio, 10:1 of methanol to oil molar ratio (One-stage). course unsuitable for solketal production. Therefore, the reaction rate for the DBSA catalyst was 24 times higher than the sulphuric acid with reported rate of 4000 times less than base catalysts [31]. This has been attributed to the surfactant ability of the DBSA catalyst [22].

The equilibrium rate constants $\left(\mathrm{K}_{\mathrm{eq}}\right)$ in Table 3 were obtained from the experimental rate constants and theoretically based on Gibbs free energy $(\Delta G)$. The theoretical $\mathrm{K}_{\mathrm{eq}}$ were calculated using Eq. 22 and Eq. 23, where $\Delta \mathrm{H}$ is the enthalpy of formation, $\Delta \mathrm{S}$ is the entropy of formation, $\mathrm{R}$ is the universal gas constant, and $\mathrm{T}$ is the reaction temperature in Kelvin. The value of $\Delta \mathrm{H}$ and $\Delta S$ of each compound were obtained from existing studies $[15,32,33]$. Table 3 shows that the experimental $\mathrm{K}_{\text {eq }}$ were substantially higher that the theoretical values from Gibbs free energies, except for the glycerol reaction with acetone. This could be attributed to the continuous removal of glycerol from the reaction mixture, which favours the forward reaction according to Le Chatelier's principle. The continuous removal of glycerol by-product indicates that reactive coupling could potentially allow for reductions in the amount of methanol required for biodiesel productions. There was no enhancement in the $\mathrm{K}_{\mathrm{eq}}$ for the solketal formation, indicating that this reaction is limited by thermodynamic equilibrium”.

$$
\begin{aligned}
& \Delta \mathrm{G}=\Delta \mathrm{H}-\mathrm{T} \Delta \mathrm{S} \\
& \Delta \mathrm{G}=-\mathrm{RT} \ln \left(\mathrm{K}_{\mathrm{eq}}\right)
\end{aligned}
$$

\subsection{Validation of the kinetic model for reactive coupling of RSO transesterification}

Figure 6 shows the RSO conversions to FAME and solketal for the two-stage process at the optimal process conditions determined from the DoE. This two-stage reactive coupling process was intended to maximise both

Table 3: Theoretical and experimental values of equilibrium rate constants at $50^{\circ} \mathrm{C}, 10: 1$ of methanol to oil molar ratio, and $4: 1$ of acetone to

\begin{tabular}{|c|c|c|c|c|c|}
\hline Rate designation & aRate constants $(\mathrm{L} / \mathrm{mol} \cdot \mathrm{s}) * 10^{-4}$ & ${ }^{\mathrm{b}}$ Rate constants $(\mathrm{L} / \mathrm{mol} \cdot \mathrm{s}) * 10^{-4}$ & $\mathrm{~K}_{\text {eq }}$ (Calc.) & $\mathrm{K}_{\mathrm{eq}}($ Exp.) & Ref. \\
\hline$T G+M A \stackrel{k 1 / k 2}{\longleftrightarrow} F A M E+D G$ & $\mathrm{k}_{1}=2.47$ & $\mathrm{k}_{2}=0.237$ & 9.82 & 10.42 & {$[32,33]$} \\
\hline$D G+M A \stackrel{k 3 / k 4}{\longleftrightarrow} F A M E+M G$ & $\mathrm{k}_{3}=3.06$ & $\mathrm{k}_{4}=2.6$ & 0.90 & 1.18 & {$[32,33]$} \\
\hline$M G+M A \stackrel{K 5 / K 6}{\longrightarrow} F A M E+G L$ & $\mathrm{k}_{5}=1.24$ & $\mathrm{k}_{6}=0.728$ & 0.02 & 1.70 & {$[32,33]$} \\
\hline$G L+A C \stackrel{K 7 / K 8}{\longleftrightarrow}$ solketal $+H 2$ & $\mathrm{k}_{7}=5.67$ & $\mathrm{k}_{8}=5.34$ & 1.19 & 1.06 & [15] \\
\hline
\end{tabular}
oil molar ratio.

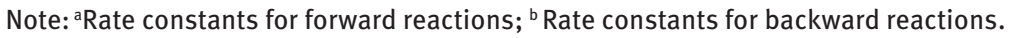




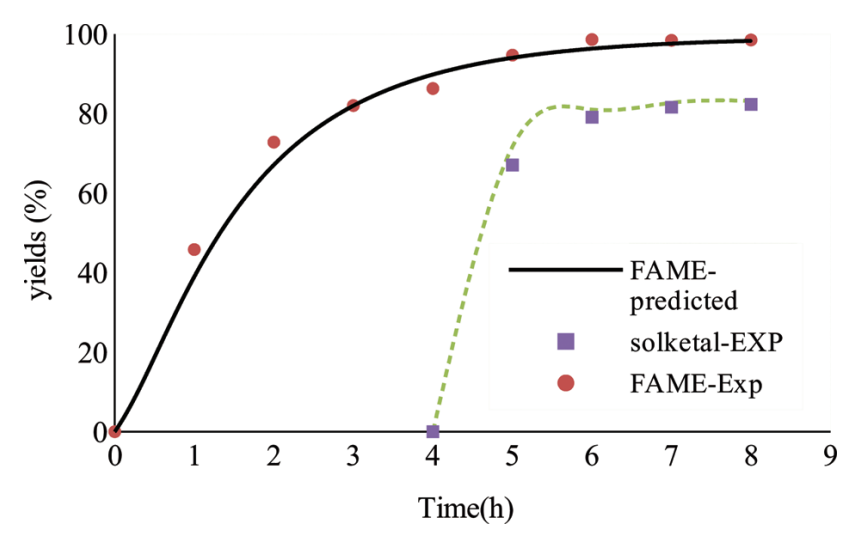

Figure 6: conversion of predicted and experimental values for reactive coupling of (solketal and FAME yield): two stage process, at $7: 1$ of acetone to oil molar ratio, $50^{\circ} \mathrm{C}, 10: 1$ of methanol to oil molar ratio and 0.5 of catalyst to oil molar ratio.

the FAME and solketal yields. In the two-stage process, the RSO transesterification was allowed to reach complete conversion to achieve high glycerol concentration in the first stage, followed by addition of the required amount of acetone. It was observed that high solketal yield (82\%) was achieved after $4 \mathrm{~h}$ reaction time (from adding acetone) or $8 \mathrm{~h}$ (total reaction time) (Figure 6) at 7:1 of acetone to oil molar ratio, which compares well with solketal yields reported elsewhere, when only using pure glycerol as reactant [30,34]. These results clearly demonstrated that adding acetone in the second stage (when high content of glycerol is formed) can lead to improve solketal yield compared to one-stage process. The experimental data for two-stage processes were used to validate the kinetic model predictions, and it was observed that there is a high agreement between them, indicating the reliability of the model as shown in Figure 6.

\section{Conclusions}

A novel process for combining triglyceride transesterification to FAME and in situ acetalisation of its glycerol by-product to solketal is reported. The aim of the study was to minimise or prevent co-production of crude glycerol, whilst maximising the solketal yield, to improve the economics of biodiesel production. A parametric study of the reactive coupling process was performed using DoE, to investigate the reaction parameters at acetone to glycerol (oil) molar ratio of 2:1 to 10:1; residence time of $1-4 \mathrm{~h}$; and silica gel loading of 0 to $100 \mathrm{wt} \%$ based on the RSO. A two-stage process with delayed introduction of some of the acetone was also studied.

It was observed that silica loading had no effect on the FAME yield, but did increase the solketal yield, as it removes the reactively-formed water from the system by up to $83 \%$, thereby pushing the equilibrium towards higher glycerol to solketal conversion. Higher solketal yields were achieved using the two-stage process, with $82 \pm 4 \%$ solketal yield, as compared to $39.5 \pm 5.1 \%$ solketal yield for the one-stage. The one-stage and twostage processes achieved ( $\geq 98 \%$ ) FAME yields. Although acetone is required for the acetalisation of the glycerol, the excess acetone reduces rates of production of both biodiesel and solketal, due to dilution. This study also established a kinetic model for the reactive coupling of RSO transesterification and glycerol conversions to solketal. This model was validated using experimental data, and was successfully used to predict both FAME and solketal yields.

Acknowledgement: The authors would like to thank the Higher Committee for Education Development in Iraq (HCED) for their financial support.

\section{References}

[1] Statistics, Biofuels production in selected countries in Europe in 2017. Statista - The portal for statistics, 2017.

[2] Rodrigues R., Isoda N., Gonçalves M., Figueiredo F.C.A., Mandelli D., Carvalho W.A., Effect of niobia and alumina as support for Pt catalysts in the hydrogenolysis of glycerol. Chem. Eng. J., 2012, 198-199, 457-467.

[3] Ciriminna R., Pina C.D., Rossi M., Pagliaro M., Understanding the glycerol market. Eur. J. Lipid Sci. Tech., 2014, 116, 1432-1439.

[4] Leoneti A.B., Aragão-Leoneti V., de Oliveira S.V.W.B, Glycerol as a by-product of biodiesel production in Brazil: Alternatives for the use of unrefined glycerol. Renew. Energ., 2012, 45, 138-145.

[5] Yang F., Hanna M.A., Sun R., Value-added uses for crude glycerol a byproduct of biodiesel production. Biotechnol.Biofuels, 2012, 5:13.

[6] Knothe G., Krahl J., Van Gerpen J., The Biodiesel Handbook (2nd Ed.). Academic Press and AOCS Press, 2010.

[7] Mu Y., Teng H., Zhang D.-J., Wang W., Xiu Z.-L., Microbial production of 1,3-propanediol by Klebsiella pneumoniae using crude glycerol from biodiesel preparations. Biotechnol. Lett., 2006, 28, 1755-1759.

[8] Papanikolaou S., Muniglia L., Chevalot I., Aggelis G., Marc I., Yarrowia lipolytica as a potential producer of citric acid from raw glycerol. J. Appl. Microbiol., 2002, 92, 737-744.

[9] Ashby R., Solaiman D.Y., Foglia T., Bacterial Poly(Hydroxyalkanoate) Polymer Production from the Biodiesel Co-product Stream. J. Polym. Environ., 2004, 12, 105-112. 
[10] Lertlukkanasuk N., Phiyanalinmat S., Kiatkittipong W., Arpornwichanop A., Aiouache F., Assabumrungrat S., Reactive distillation for synthesis of glycerol carbonate via glycerolysis of urea. Chem. Eng. Process.: Process Intensification, 2013, 70,103-109.

[11] Kiatkittipong W., Intaracharoen P., Laosiripojana N., Chaisuk C., Praserthdam P., Assabumrungrat S., Glycerol ethers synthesis from glycerol etherification with tert-butyl alcohol in reactive distillation. Comput. Chem. Eng., 2011, 35, 2034-2043.

[12] KiatkittipongW., SuwanmaneeS., Laosiripojana N., Praserthdam P., Assabumrungrat S., Cleaner gasoline production by using glycerol as fuel extender. Fuel Process. Techn., 2010, 9145691460.

[13] Mota C.J.A., da Silva C.X.A., Rosenbach N., Costa J., da Silva F., Glycerin Derivatives as Fuel Additives: The Addition of Glycerol/ Acetone Ketal (Solketal) in Gasolines. Energ. Fuel., 2010, 24, 2733-2736.

[14] Nanda M.R., Yuan Z., Qin W., Ghaziaskar H.S., Poirier M.-A., Xu C., Catalytic conversion of glycerol to oxygenated fuel additive in a continuous flow reactor: Process optimization. Fuel, 2014, 128,113-119.

[15] Rossa V., Pessanha Y, Díaz G.C., Câmara L.D.T., Pergher S.B.C., Aranda D.A.G., Reaction Kinetic Study of Solketal Production from Glycerol Ketalization with Acetone. Ind. Eng. Chem. Res., 2017, 56, 479-488.

[16] Melero J.A., Vicente G., Morales G., Paniagua M., Bustamante J., Oxygenated compounds derived from glycerol for biodiesel formulation: Influence on EN 14214 quality parameters. Fuel, 2010, 89, 2011-2018.

[17] Alhassan Y., Kumar N., Bugaje I.M., Pali H.S., Kathkar P., Co-solvents transesterification of cotton seed oil into biodiesel: Effects of reaction conditions on quality of fatty acids methyl esters. Energ. Convers. Manage., 2014, 84, 640-648.

[18] Luu P.D., Takenaka N., Van Luu B., Pham L.N., Imamura K., MaedaY., Co-solvent Method Produce Biodiesel form Waste Cooking Oil with Small Pilot Plant. Energy Proced., 2014, 61, 2822-2832.

[19] PetchsoongsakulN., Ngaosuwan K., KiatkittipongW., AiouacheF., Assabumrungrat S., Process design of biodiesel production: Hybridization of ester-and transesterification in a single reactive distillation. Energ. Convers. Manage., 2017, 153, 493-503.

[20] Eze V.C., Harvey A.P., Continuous reactive coupling of glycerol and acetone - A strategy for triglyceride transesterification and in-situ valorisation of glycerol by-product. Chem. Eng. J., 2018, 347, 41-51.
[21] Dmitriev G.S., Terekhov A.V., Zanaveskin L.N., Khadzhiev S.N., Zanaveskin K.L., Maksimov A.L., Choice of a catalyst and technological scheme for synthesis of solketal. Russ. J. Appl. Chem.+, 2016, 89, 1619-1624.

[22] Alegría A., Arriba Á.L.F., Morán J.R., Cuellar J., Biodiesel production using 4-dodecylbenzenesulfonic acid as catalyst. Appl. Catal. B-Environ., 2014, 160-161, 743-756.

[23] BS EN 14103, Fat and oil derivatives - Fatty acid methyl esters (FAME) for diesel engines - Determination of esters and linolenic acid methyl ester contents. In: British standerd. Chiswick High Road, London, 2003, 1-11.

[24] Freedman B., Butterfield R., Pryde E., Transesterification kinetics of soybean oil 1. J. Am. Oil Chem. Soc., 1986, 63, 1375-1380.

[25] Noureddini H., Zhu D., Kinetics of transesterification of soybean oil. J. Amer. Oil Chem. Soc., 1997, 74, 1457-1463.

[26] Darnoko D., Cheryan M., Kinetics of palm oil transesterification in a batch reactor. J. Amer. Oil Chem. Soc., 2000, 77, 1263-1267.

[27] Vicente G., Martínez M., Aracil J., Esteban A., Kinetics of sunflower oil methanolysis. Ind. Eng. Chem. Res., 2005, 44, 5447-5454.

[28] Eze V.C., Phan A.N., Harvey A.P., A more robust model of the biodiesel reaction, allowing identification of process conditions for significantly enhanced rate and water tolerance. Bioresource Technol., 2014, 156, 222-231.

[29] Eze V.C., Phan A.N., Harvey A.P., Intensified one-step biodiesel production from high water and free fatty acid waste cooking oils. Fuel, 2018, 220567-220574.

[30] Menezes F.D.L., Guimaraes M.D.O., da Silva M.J., Highly Selective $\mathrm{SnCl}_{2}$-Catalyzed Solketal Synthesis at Room Temperature. Ind. Eng. Chem. Res., 2013, 52, 16709-16713.

[31] Boz N., Degirmenbasi N., Kalyon D.M., Esterification and transesterification of waste cooking oil over Amberlyst 15 and modified Amberlyst 15 catalysts. Appl. Catal. B-Environ., 2015, 165, 723-730.

[32] Zeng D., Li R., Jin T., Fang T., Calculating the Thermodynamic Characteristics and Chemical Equilibrium of the Stepwise Transesterification of Triolein Using Supercritical Lower Alcohols. Ind. Eng. Chem. Res., 2014, 53, 7209-7216.

[33] Kieffer W.F., CRC Handbook of Chemistry and Physics, 54th Edition. J. Chem. Ed., 1975, 52, A142.

[34] Nandan D., Sreenivasulu P., Sivakumar Konathala L.N., Kumar M., Viswanadham N., Acid functionalized carbon-silica composite and its application for solketal production. Micropor. Mesopor. Mat., 2013, 179, 182-190. 